\title{
千葉県九十九里浜一松海岸の侵食実態と 今後の対策の方向性 \\ EROSION OF HITOTSUMATSU BEACH ON KUJUKURI COAST AND FUTURE MEASURES AGAINST BEACH EROSION
}

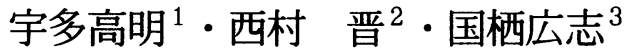

Takaaki UDA, Susumu NISHIMURA and Hiroshi KUNISU

\author{
${ }^{1}$ 正会員 工博 建設省土木研究所河川部長（干305-0804 茨城県つくば市旭 1) \\ ${ }^{2}$ 正会員 財団法人土木研究センター 研究開発一部 ( $1110-0016$ 東京都台東区台東 1-6-4) \\ ${ }^{3}$ 正会員 工博 財団法人土木研究センター 研究開発一部（テ110-0016 東京都台東区台東 1-6-4）
}

\begin{abstract}
Beach erosion of the Hitotsumatsu beach on the Kujukuri coast in Chiba Prefecture facing the Pacific Ocean was investigated by field observations in 1997 and 1998. The Kujukuri coast has been formed by the deposition of sediment supplied from the sea cliffs located both ends of a $60 \mathrm{~km}$ long stretch of coastline. Disappearance of sand source of the sea cliff due to the construction of wave dissipating works on foot of sea cliff as a measure against erosion and obstruction of continuous sand movement by breakwaters of the harbors caused severe beach erosion on the downcoast. Here such a situation is studied and future measures against beach erosion is discussed.
\end{abstract}

Key words : Beach erosion, Kujukuri coast, measures, field observation

1.まえがき

一方向の卓越沿岸漂砂がある海岸において漂砂源の 枯渴が起きた場合、海岸侵食によって生じる侵食域は 時間経過とともに下手側へと次々に広がりを示す。侵 食域の広がりに対して侵食対策がそれに追いつかず、 海岸線の人工化が急速に進んでしまった海岸は非常に 多いが、千葉県九十九里海岸もこのような状況が起こ りつつある海岸の一つである。この海岸は北端に位置 する屏風ヶ浦と南端に位置する太東崎の海食崖からの 供給土砂が長い年月を経て沿岸漂砂によって中央部に 運ばれ、堆積して形成されたものであるが、ここ 20 〜30 年間でこれらの海食崖に侵食対策としての消波 堤が建設されて侵食が防がれ、海岸への供給土砂量が 減少するとともに、九十九里海岸の北端部では飯岡漁 港の防波堤が、また南端部では太東漁港の防波堤が建 設されて沿岸漂砂の連続性が妨げられた結果、北部(北 九十九里海岸と吉崎海岸) と南部(一宮海岸と一松海 岸)で激しい侵食に見舞われている。

九十九里浜の南部では、1997 年 9 月 19 日に来襲し た台風 20 号にともなう高波浪によって一宮川の河口 周辺で激しい侵食が起きた。このため、その侵食状況
について同年 10 月 30 日に調查し、結果をとりまとめ た ${ }^{1)}$ 。また、ほぼ 1 年後の 1998 年 11 月 18 日に改め て現地調査を行ったところ、海岸侵食がさらに深刻化 していることが見いだされた。そこで、本研究はこれ らの現地調査によって侵食実態を明らかにした上でこ の海岸における今後の対策の方向性について検討を加 える。

\section{2. 一宮・一松海岸の概況と 9720 号台風に伴う高波浪}

九十九里海岸における地先海岸名と調査区域の位置 を図-1 ${ }^{2)}$ に示す。図-1によると調查地の一宮川河口付 近は九十九里海岸の南部に位置し、河口の南約 $8 \mathrm{~km}$ に は太東崎が、また北約 $7 \mathrm{~km}$ には南白亀川河口が位置 しており、一宮川河口を挟んで北側は一松海岸、南側 は一宮海岸と呼ばれている。また一宮川河口付近での 沿岸漂砂の卓越方向は北向きであって、周辺にある主 な構造物としては、一宮川の河口導流堤を中心として 南側に 7 基のヘッドランドが、また北約 $7 \mathrm{~km} に$ には南 白亀川の河口導流堤が伸びている。

1997 年 9 月 19 日房総半島沖を通過した台風 20 号 は、伊豆諸島を暴風圈に巻き込んだ後、房総半島を 


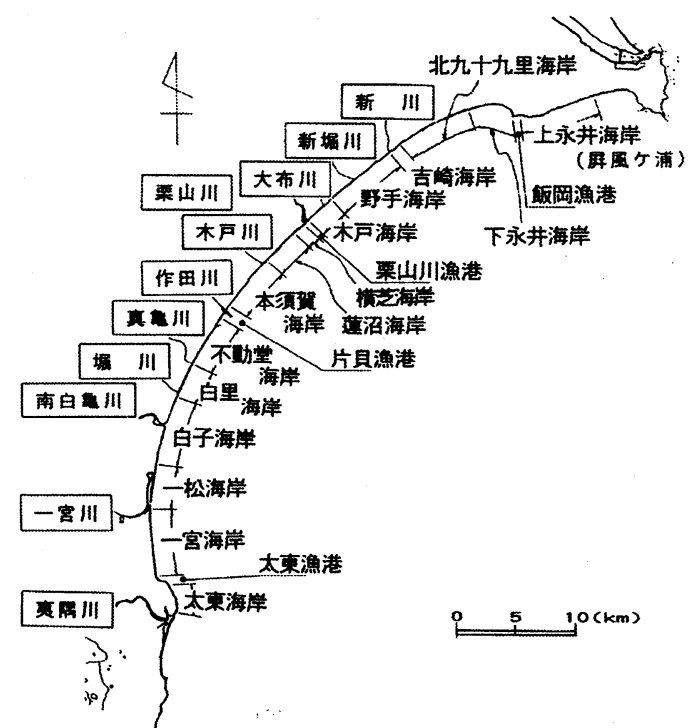

図-1 九十九里海岸における一宮川河口位置と海岸地先名

かすめるようにして東太平洋へと進行した。この台風 では片貝漁港沖で有義波高 4〜 5m、周期が 14〜 15s という高波浪が記録され、しかも長く続いた ${ }^{11}$ 。

\section{3. 一宮・一松海岸の侵食状況（1997 年 10 月 30 日）}

宇多2)、3)に述べられているように、一宮海岸では 北向きの沿岸漂砂量の均衡が崩れたために侵食が進ん できている。このため 1997 年 10 月までに 7 基のヘッ ドランドが設置された。ヘッドランドは、北から南へ 順に 1〜 7号堤と呼ばれる。ヘッドランドの設置区間 では海岸護岸として緩傾斜堤が造られている。以下で は、まず宇多ら ${ }^{1)}$ を参照して、1997 年 10 月 30 日の 海岸状況を明らかにする。

写真-1 は、一宮川河口の右岸（南）側直近まで延ば された緩傾斜堤の北端部の状況である。南からの沿岸 漂砂が枯渴状態にあるために、緩傾斜堤の端部が大き くえぐられて汀線が後退し、浜崖が形成されている。 なお、この浜崖は沿岸漂砂の卓越している場において 汀線付近に構造物が設置されたことによって形成され たものであるから、緩傾斜堤の端部処理に工夫を加え たとしても同様に浜崖が形成される結果となる。写真 -2 は、写真-1において駐車している車のうち、最も陸 側に位置する車付近から北側の海浜を撮影したもので ある。緩傾斜堤のすぐ裏側では非常に高い浜崖が形成 されているが、北側に離れると次第に高さが減少し前 浜勾配も小さくなる。写真-3 は、写真-2 の左端での浜 崖形成状況である。ここでの浜崖の高さは約 $3 \mathrm{~m}$ に達 している。この位置より北側の写真-2において中央に 4 人が見える付近での浜崖の形成状況を示すのが写真 -4 である。浜崖の高さは約 $1.6 \mathrm{~m}$ に低下し、地層の下 部には粘性土層も見られる。さらに一宮川河口に接近 すると、写真-5に示すように浜崖の高さはずっと低く

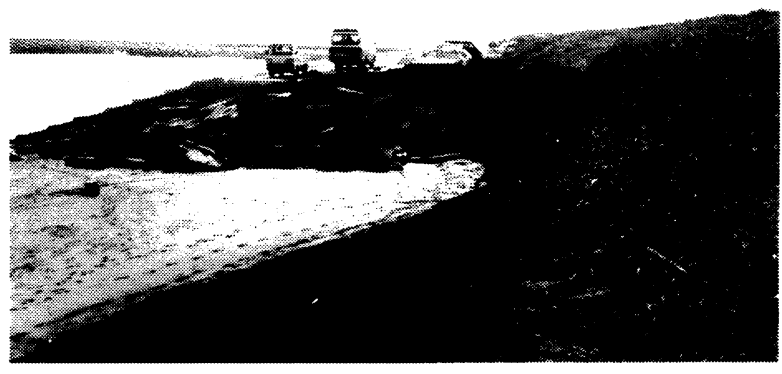

写真-1 一宮海岸緩傾斜堤の北端部

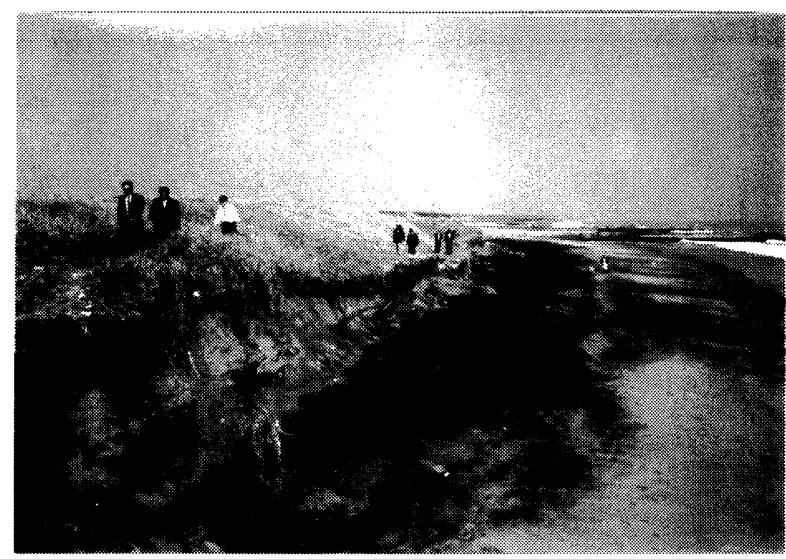

写真-2 一宮海岸緩傾斜堤の北側に形成された浜崖

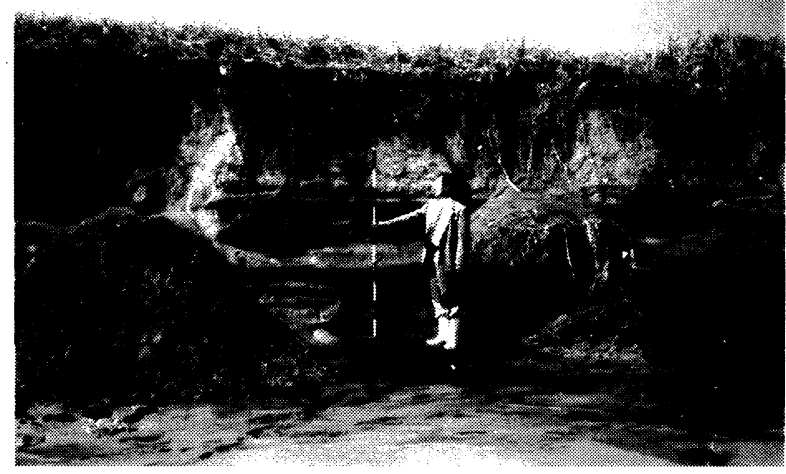

写真-3 最も高い浜崖の露頭

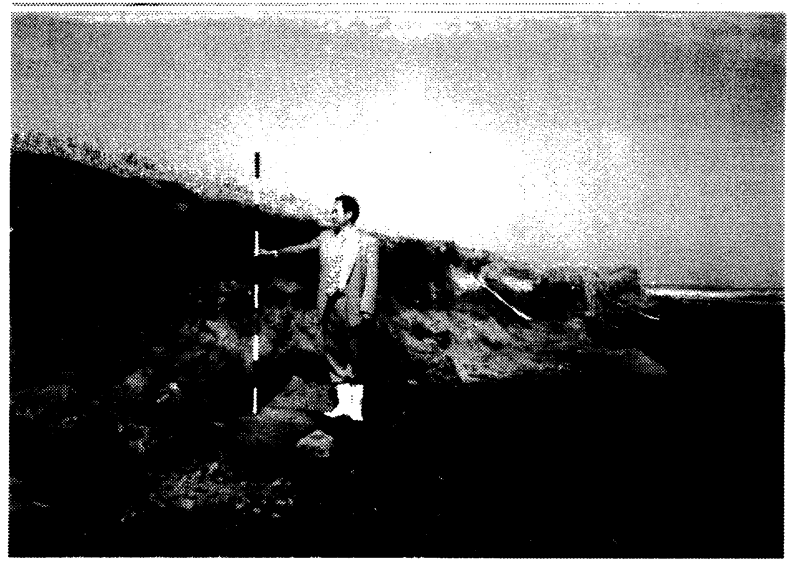

写真-4 写真-3 北側での浜崖形成状況 
なるが、現況の砂面のすぐ上部には粘性土層が広く覆 っている。この層はもともと一宮川の流送土砂が堆積 したものであるが、その堆積層が海岸侵食で露出する ようになったことは、この付近の海岸侵食が過去に例 を見ないほど進んできていることを示している。以上 のように、1997 年 10 月 30 日当時、一宮海岸では緩 傾斜堤の北端部において激しい侵食が生じていた。

一宮川の河口導流堤はヘッドランドと同様、海に突 き出た構造を有する。1997 年 10 月 30 日の現地踏査 によれば、一宮川の河口右岸（南）側での浜崖形成と 同時に、導流堤の北側、すなわち一松海岸でも浜崖侵 食が進んでいることが見いだされた。写真-6に示すよ うに、導流堤の北側隣接域では大きく汀線が後退し、 浜崖が延々と形成されている。写真-7 は、写真-6 の左 端付近における浜崖形成状況である。高さ約 $1.4 \mathrm{~m}$ の 浜崖が形成されている。砂層の上部には約 $0.6 \mathrm{~m}$ 厚の 粘性土が被さっているが、この土は管理用道路を建設 する際に盛土されたものである。ここよりさらに北側 での浜崖の形成状況を写真-8 に示す。この付近では浜 崖の形成によって砂丘に生えていた植物の根が露出す るとともに、それらが土砂とともに崩落している。写 真-9 は、浜崖形成範囲の北端部付近の浜崖状況である。 ここでの浜崖の高さは約 $1 \mathrm{~m}$ となる。このように一宮 川の河口導流堤からの距離が離れるにしたがい、浜崖 の高さは低くなっている。また写真-10 は、海岸線背後

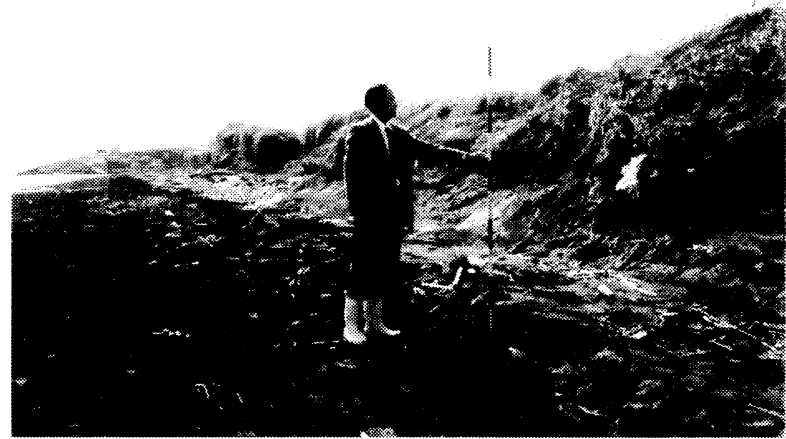

写真-5 浜崖侵食によって現れた、一宮川の流砂土砂によっ て形成され、表面を飛砂で覆われた土層

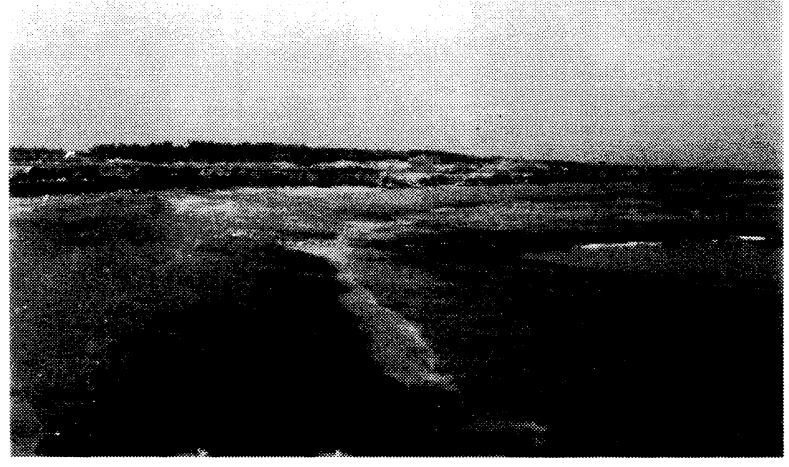

写真-6 一宮川左岸（北）側の汀線後退域

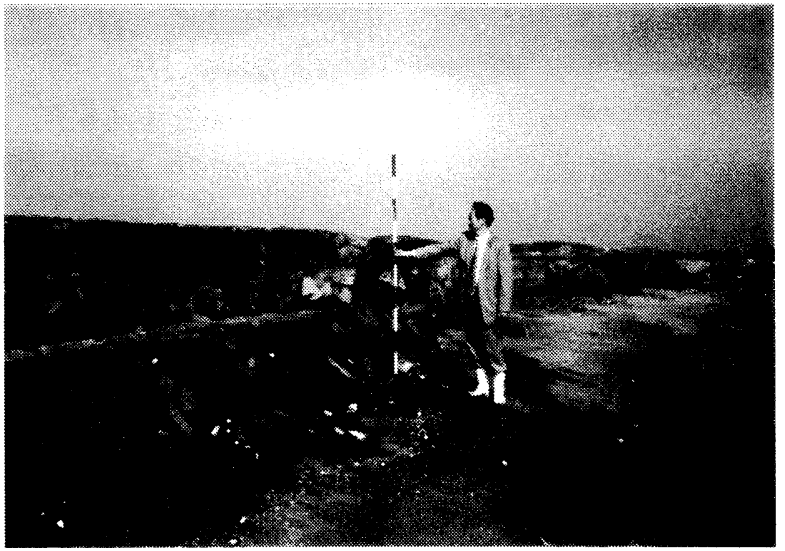

写真-7 一宮川左岸導流堤近傍の浜崖侵食

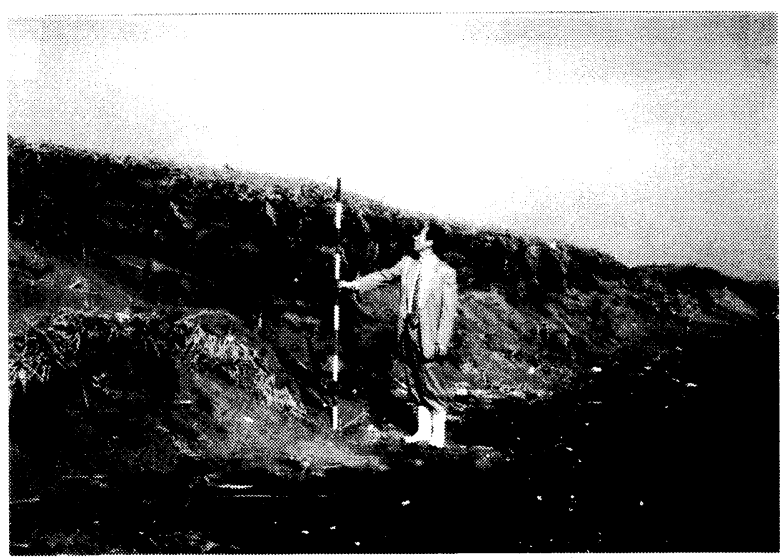

写真-8 写真-7 よりさらに北側における浜崖侵食状況

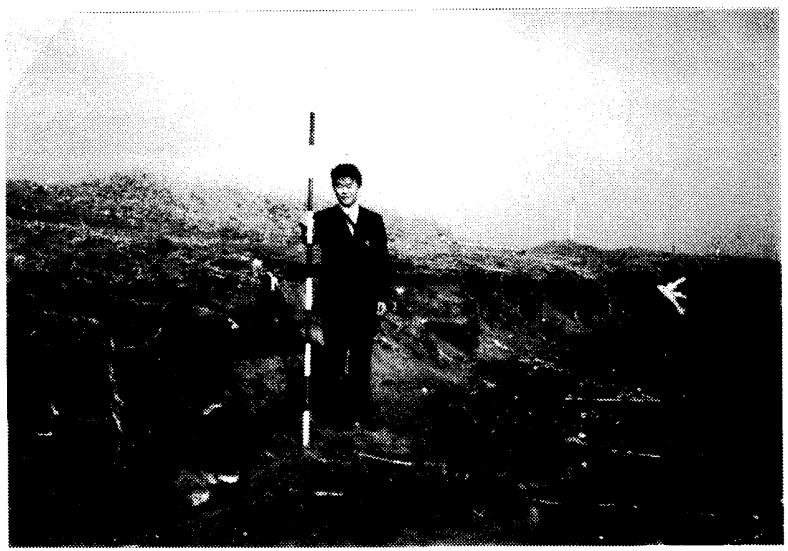

写真-9 写真-8よりさらに北側における浜崖侵食状況

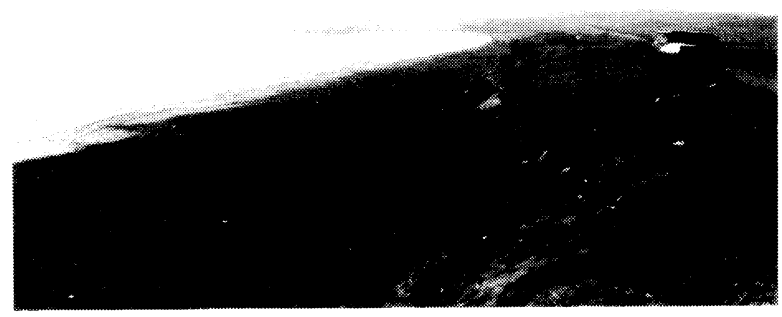

写真-10 一宮川左岸導流堤北側に形成された汀線の湾入部 
のやや小高い場所から一宮川河口導流堤を遠望したも のであるが、導流堤のすぐ北 (手前) 側の汀線が大き く後退して湾入しているのがよく分かる。以上のよう に、1997 年 10 月 30 日当時、一宮川河口北側の一松 海岸では汀線の後退と浜崖の形成が進み、管理用道路 が侵食されたことから、侵食から道路を守るために災 害復旧として緩傾斜堤が河口導流堤から延長 $180 \mathrm{~m}$ に わたって建設された。

\section{4.一松海岸の侵食状況（1998 年11月18日）}

前回調査から約 1 年が経過した 1998 年 11 月 18 日 に再び一松海岸の現地調查を行った。

写真-11 は、一松海岸の緩傾斜堤上から北側を望んで 撮影したものである。災害復旧で緩傾斜堤が造られた が、この付近では沿岸漂砂が卓越しているために、緩 傾斜堤の建設後直ちに侵食域が北側に広がることにな つた。写真-11で前方に見える北端部を撮影したのが写 真-12である。アスファルト舗装された緩傾斜堤の天端 面が急激に切れ、その先には連続的に浜崖が形成され ている。緩傾斜堤はその位置で汀線を固定し、それ以 上の汀線後退を許さないために、そのすぐ北側で大き く侵食が進んだのである。この結果、1997 年 10 月 30 日には一部が欠け込んでいた管理用道路は緩傾斜堤の 隣接部で完全に侵食され、跡形もなくなった。写真-13 は、緩傾斜堤の端部を北側から撮影したものである。 端部を保護するために土囊が置かれているが、写真左 端に確認されるようにすでに土囊の沈下とその背後の 土砂の流出が起きている。緩傾斜堤の北端部での浜崖 の形成状況は、写真-1 に示した一宮川河口右岸側で 1997 年 10 月 30 日に見られた状況と全く同様である。 緩傾斜堤の北端部の位置が北側に約 $180 \mathrm{~m}$ 移動したの とあわせて、浜崖の形成箇所が北側に移動したのみで ある。

写真-14 は、写真-12 において緩傾斜堤の天端面の延 長上に見える、数台の車の位置付近に形成されている 浜崖の状況を撮影したものである。この付近では約 $1.7 \mathrm{~m}$ の浜崖が形成されている。写真-15は、写真-14 の 撮影位置よりわずかに北側から浜崖形成区域を眺めた ものである。写真左端に見えるのが緩傾斜堤であり、 そこから浜崖が連続的に形成されていることがよく分 かる。写真-16 は、写真-15 の撮影地点よりさらに北側 での浜崖形成状況である。ここでは約 $2 \mathrm{~m}$ の浜崖が形 成されており、砂丘上の植生の根が露出している。浜 崖下部には砂の斜面が形成されているが、これは植生 直下の砂が崩落し、海浜上に安息角をなして堆積した ものと考えられる。写真-16 の右端近くの砂丘上に立つ た墓碑（この墓碑はここ付近の海岸で水死した女性の ものである) の前面での浜崖形成状況を示すのが写真 -17 である。ここでも浜崖の高さは約 $2 \mathrm{~m}$ に達する。

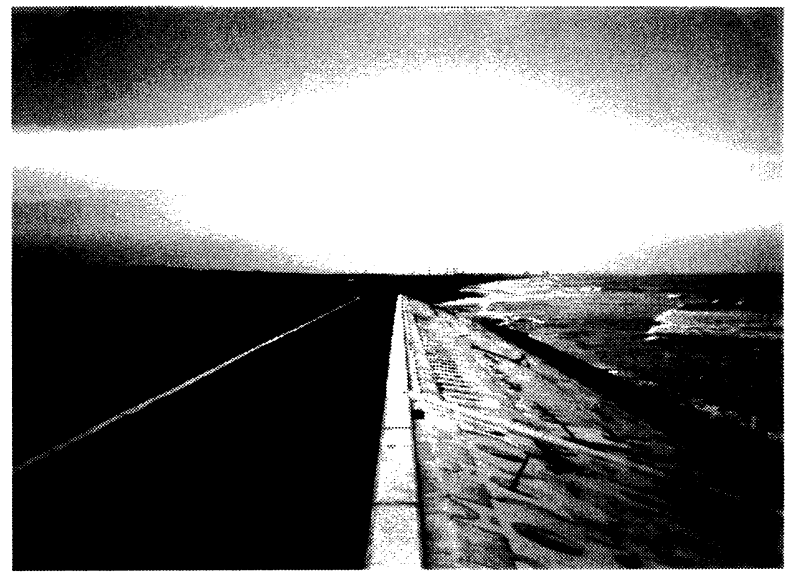

写真-11 一宮川河口左岸に位置する一松海岸の緩傾斜堤
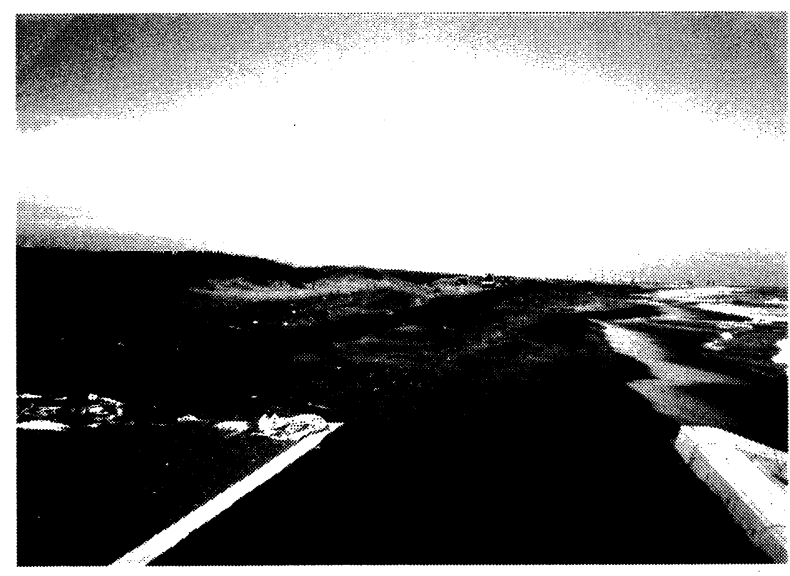

写真-12 緩傾斜堤の北端部に形成された浜崖

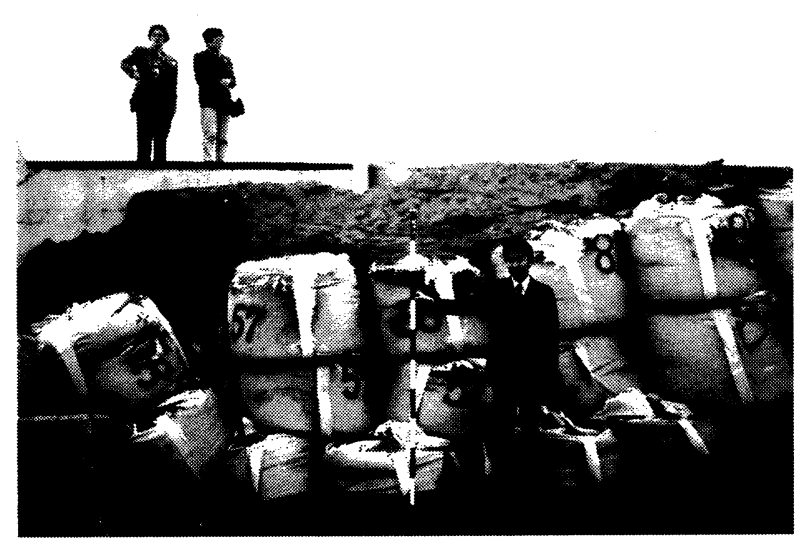

写真-13＼cjkstart緩傾斜堤端部の崩れつつある土囊

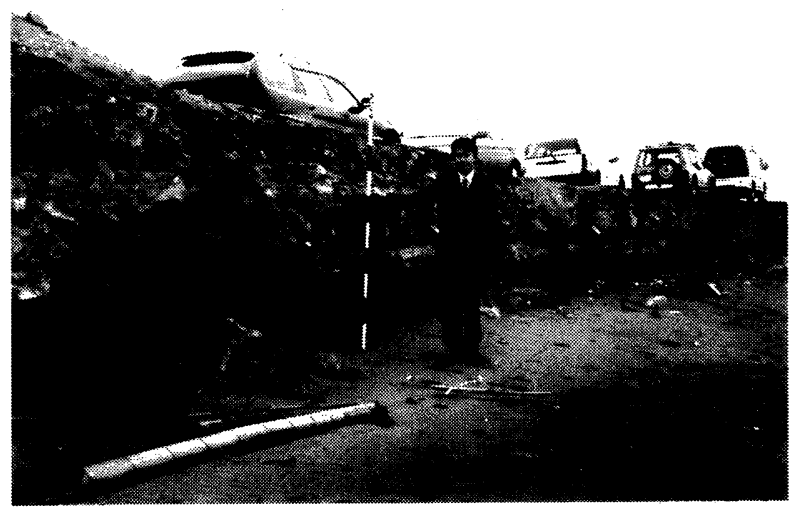

写真-14 管理用道路を切り込んで形成された約 $1.7 \mathrm{~m}$ の浜崖 
この場所では地中に埋まっていた大きな流木が侵食に よって大きく露出していることが分かる。写真-18 は、 再び一宮川の河口方面を望んで撮影したものである。 写真中央に見える緩傾斜堤から連続的に浜崖が形成さ れていることがよく分かる。

\section{5. 考察}

1997 年 10 月 30 日の現地調査当時、一宮川の河口 右岸側では緩傾斜堤が建設され、その北側端部で浜崖 侵食が起きていた。そして 1998 年 11 月 18 日の調査 では、新たに一宮川河口の左岸側に位置する一松海岸 に緩傾斜堤が建設され、その北端部に再び浜崖が形成 されていた。観察された浜崖の状況は、前回見られた ものと全く同じである。相違点は、ただ単に浜崖の形 成䈯所が緩傾斜堤の伸びた分だけ北側へ移動したこと である。このような状況は一方向の沿岸漂砂が卓越す る海岸に緩傾斜堤が建設された場合、共通して見られ る現象である。よって、このような漂砂条件下におい て浜崖がわずかでも形成されている場所に侵食対策と して緩傾斜堤を造れば、必ずその端部には浜崖が形成 され、その対策として緩傾斜堤が延長されることにな る。このような侵食と対策を繰り返すことにより次々 と緩傾斜堤の区域は北側へと拡大し、数年後には砂浜 海岸全体が緩傾斜堤で埋め尽くされ、階段工の前面に は砂浜が全く見られないという事態となることを意味 している。したがって、これらを踏まえ一松海岸は今 後どのような侵食対策がなされるべきか以下に考察す る。

一松海岸の現況では南側からの沿岸漂砂の供給はほ とんどなくなっている。その理由として、もともと漂 砂の供給源であった太東岬の海食崖の侵食防止工事が 行われて海食崖からの供給土砂量が減少したこと、太 東漁港の防波堤が北向きの沿岸漂砂移動を阻止してい ること、一宮海岸には 7 基のへッドランドの突堤部分 （約 $150 \mathrm{~m}$ ）が完成して北向きの沿岸漂砂の流出を阻 止していること、さらには一宮川の河口導流堤もまた 北向きの沿岸漂砂の移動を阻害していることである。 この海岸では時間が経過しても自然的要因によって沿 岸漂砂の供給量が増加することはないので、長期的に 見れば侵食傾向は強くなることはあっても、堆積傾向 になることはない。一方、この海岸にそもそも緩傾斜 堤が造られたのは、管理用道路が侵食されており、侵 食されたままで放置できないことによる。しかし、緩 傾斜堤では新たに侵食箇所を広げることになることは 本研究で調査したとおりである。その場合、考えられ る対策は次のとおりである。まずは沿岸漂砂の供給が 枯渴状態にあることから、この区間においても海浜の 静的安定化を目指すことである。これには一宮海岸で 行われている対策工と同様のへッドランドを建設して、

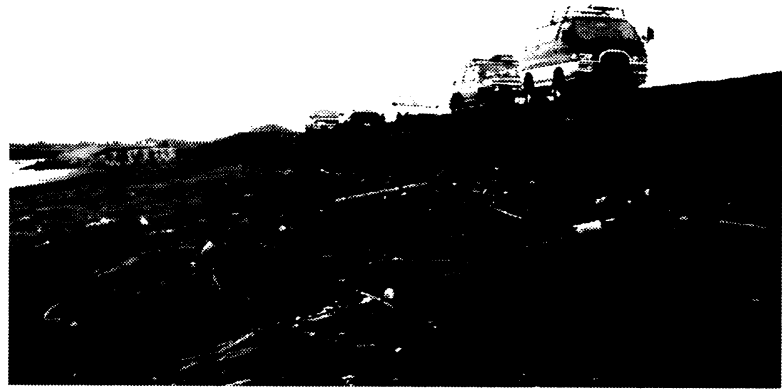

写真-15 浜崖形成区間と緩傾斜堤

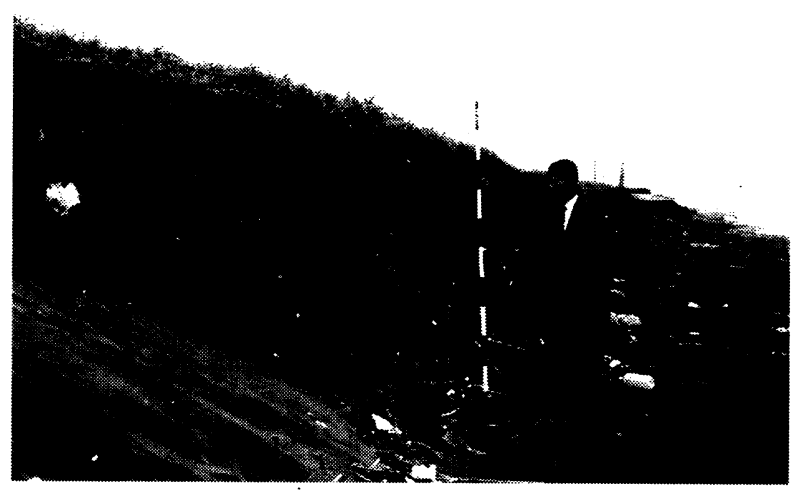

写真-16 浜崖侵食と植生状況

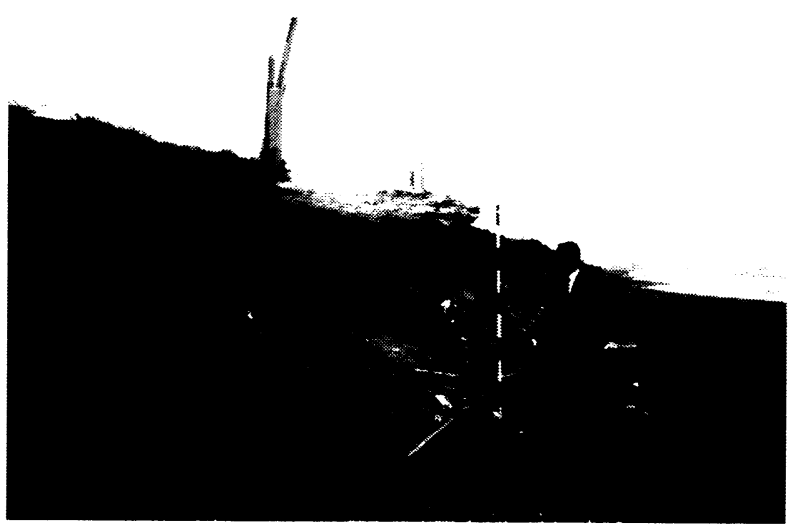

写䡩-17 写真-16 の左端近くの砂丘に立った墓碑前面での 浜崖形成状況

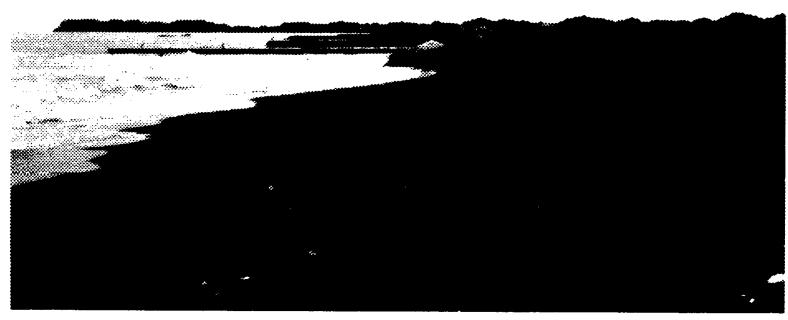

写真-18 一宮川河口方面を望んだ侵食状況 


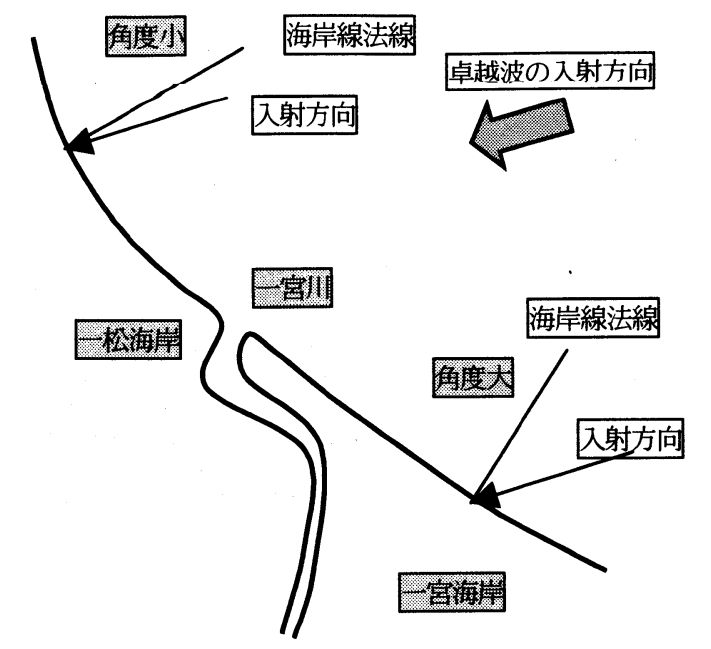

図-2 海岸線法線と卓越入射波の方向とのなす角

適切な間隔で海岸線を分割し海岸線の安定化を図るこ とである。一宮海岸で建設中のへッドランドは沿岸方 向に約 $1 \mathrm{~km}$ 間隔で配置されている。この場合、図-2 に示すように一宮海岸における海岸線への法線と卓越 波の入射方向とのなす角に対し、一松海岸ではその角 度が小さいので、ヘッドランドの間隔をさらに広げる ことも可能であると考えられる。また、一宮川の河口 導流堤の北約 $7 \mathrm{~km}$ に位置する南白亀川の河口導流堤 まで沿岸漂砂の移動を大きく阻害するような固定境界 条件を与える構造物は存在しない。そこで一宮川河口 から南白亀川河口までを一連区間としてその間の海岸 線を安定化させることが必要である。また、ヘッドラ ンドではそれが突堤状の場合、沿岸流の上手側では強 い離岸流が発生する ${ }^{3)}$ 。この流れは、例えば海水浴場 としての機能に影響したり、あるいはこの地区で行わ れている地引網などにも大きく影響するであろう。し たがって、これらの影響を十分検討した上で、それら の配置を決める必要がある。

また、ヘッドランドは海岸線と直交する方向に伸ば されるので、海岸線を分断し、景観や漁業上好ましく ないという考え方がある。そして、これに代わって人 エリーフや離岸堤を建設するという案もある。この場 合、人エリーフでは沿岸漂砂の移動量を小さくするこ とはできても、最終的には沿岸漂砂は流出してしまう ために安定海浜は形成されず、しかも没水構造物であ るために、漁船 (この付近ではシラス漁が盛んである) の安全確保上問題が起こる。また、従来型の離岸堤も 人エリーフと同様であり、またこの場合には建設後、 消波ブロックの沈下が起きるたびに嵪上げが必要であ り、さらには沿岸漂砂が下手側へと通過してしまい、 安定海浜を形成させることが難しい。これらのことを 考慮すると人エリーフや離岸堤の採用はかなり難しい と考えられる。
太平洋に直接面した海岸では、波による地形変化の 限界水深は約 $10 \mathrm{~m}$ にあり、それより浅い海域の土砂 は沿岸漂砂によって移動することができる ${ }^{3)}$ 。ここで 提案したへッドランドは完成してもその先端水深は約 $3 \mathrm{~m}$ 程度であろう。そうであるとすれば、ヘッドラン ドの先端を沿岸漂砂の一部は通過し、下手側へと流れ ることになるが、これは離岸堤の場合も同様である。 したがって、沿岸漂砂の移動を完全に固定しようとす れば海岸線から $2 \mathrm{~km}$ ほども大きく突き出た人工構造 物を造らない限り、静的に安定な海岸線を造ることは できない。しかし、これは現実的に計画が不可能な案 である。したがって、これらの対策としてヘッドラン ドを越えて流出してしまう沿岸漂砂に見合った土砂を 人工的に補給することが必要なことを意味している。 その場合、ヘッドランドがあれば沿岸漂砂量自体が小 さくなるので、施設がない状況と比較して養浜量を小 さくすることができることが利点である。結局のとこ ろ、単に施設で対応するのではなく、一宮川北約 $18 \mathrm{~km}$ に位置する片貝漁港までを漂砂移動の一連区間と考え、 その間の堆積域から一松海岸へと人工的に砂を運び、 養浜する方法を併用することが必要である。

\section{6.あとがき}

沿岸漂砂の枯渴に起因した海岸侵食への対策では、 その侵食原理に基づいた対策を行うことが必要である。 それに基づかない策を当面の緊急的措置として行うこ とは可能であるが、その場合、復旧箇所は 1 2 年の うちにさらに侵食されて海浜地盤高が低下し、復旧箇 所が壊れることになる。それ自身は再び直せばよいが、 短い期間に一連の海岸線が完全に人工構造物に覆われ る。一松海岸の場合には少なくとも南白亀川河口まで 約 $7 \mathrm{~km}$ は一連区間と見なければならず、この区域全 体で人工化が進んでしまうことを意味する。それを防 止するために早期に合理性のある対策を取る必要があ る。

\section{参考文献}

1) 宇多高明・西村 晋・国栖広志 (1998): 9720 号 台風による九十九里海岸南部一宮川河口部周辺での 海岸侵食、建設省土木研究所・(財) 土木研究セン夕 一「九十九里浜の巡検」 $\mathrm{pp} .2-15$.

2) 宇多高明 (1996) : 海岸における地形学的視点の 重要性、日本地形学連合編「地形学から工学への提 言」第 4 章、pp.109-138.

3) 宇多高明 (1997) : 日本の海岸侵食、山海堂、p.442.

(1999.4.19 受付) 